\title{
Fish associated with aquatic macrophytes in the Chacororé-Sinhá Mariana Lake system and Mutum River, Pantanal of Mato Grosso, Brazil
}

\author{
Pacheco, EB. and Da-Silva, CJ. \\ Instituto de Biociências, Programa de Graduação em Ecologia e Conservação da Biodiversidade, \\ Universidade Federal de Mato Grosso - UFMT \\ Av. Fernando Corrêa da Costa, s/n, Coxipó, CEP 78060-900, Cuiabá, MT, Brazil \\ Received February 20, 2008 - Accepted April 11, 2008 - Distributed February 28, 2009
}

(With 8 figures)

\begin{abstract}
On the left bank of the Cuibá River, one of the main tributaries of the Pantanal in Mato Grosso, are located the Chacororé and Sinhá Mariana Lakes and the Mutum River, the littoral regions of which are covered with aquatic macrophytes, dominated by the species Eichhornia crassipes and Eichhornia azurea. To examine the ichthyofauna associated with this vegetation, in the year 2003, 3510 fish were collected, distributed among 83 species, and the limnological variables verified near the macrophyte stands where they were sampled. The most abundant and richest order was the Characiformes, followed by the Gymnotiformes and Siluriformes. Analysis of similarity showed a very low, or null, index that the limnological conditions and morphology of the aquatic macrophyte species provide habitat sufficiently homogeneous to give. The limnological conditions and morphology of the aquatic macrophyte species provide a sufficient habitat heterogeneity to give very low, or null, index values. Thus, environmental conservation measures should be more effective in promoting the conservation of the species, given the high levels of biological diversity found in the habitats studied.
\end{abstract}

Keywords: Pantanal, fish ecology, aquatic macrophytes, Characiformes.

\section{Peixes associados a macrófitas aquáticas no sistema de baías Chacororé-Sinhá Mariana e rio Mutum, Pantanal - MT}

\begin{abstract}
Resumo
À margem esquerda do rio Cuiabá, um dos principais afluentes do Pantanal matogrossense, estão localizadas as baías Chacororé e Sinhá Mariana e o rio Mutum, cujas regiões litorâneas são cobertas por macrófitas aquáticas. Com o intuito de se verificar a ictiofauna associada a esta vegetação, no ano de 2003, foram coletados 3510 peixes distribuídos em 83 espécies e verificados os valores das variáveis limnológicas próximo aos bancos de macrófitas onde estes foram amostrados. A ordem mais abundante e de maior riqueza foi Characiformes, seguida por Gymnotiformes e Siluriformes. As condições limnológicas e a morfologia das espécies de macrófitas proporcionam heterogeneidade de hábitat suficiente para obtenção de valores dos índices de similaridade baixos ou mesmo nulos. Assim, medidas de conservação ambiental devem ser mais eficientes, de forma que promovam a conservação das espécies, visto que os hábitats estudados mostraram valores elevados de diversidade biológica.
\end{abstract}

Palavras-chave: Pantanal, ecologia de peixes, macrófitas aquáticas, Characiformes.

\section{Introduction}

The neotropical region has an extremely rich freshwater fish fauna, with 4,475 valid species recognized and another estimated 1,500 not yet described (Reis et al., 2003), of which 263 occur in the Pantanal (Britski et al., 1999).

The littoral regions of the rivers and lakes of the Pantanal are lined with aquatic macrophytes, whose production and accumulation of biomass vary in time and space (da Silva and Esteves, 1993; Penha et al., 1998). Although 240 species of macrophytes occur in the Pantanal (Pott and Pott, 1997), the predominant species in the Chacororé-Sinhá Mariana Lake system are Eichhornia crassipes (Mart.) Solms and E. azurea Kunth (Pinto et al., 1999; Nunes, 2003).

Various publications have been written about the ichthyofauna of the Pantanal (Catella and Petrere, 1996 and 1998; Súarez, 1998; Moura, 2000; Oliveira and Nogueira, 2000; Resende, 2000; Wantzen et al., 2002; Machado, 2003), but few have focused on the relationship between fish and aquatic macrophytes. 
Considering the importance of aquatic macrophytes for the ichthyofauna in general, and the different limnological conditions observed in the Chacororé-Sinhá Mariana Lake system and the Mutum River, this study was undertaken to characterize the composition and structure of the fish communities that occur in stands composed of E. crassipes or E. azurea species.

\section{Material and Methods}

The Chacororé and Sinhá Mariana Lakes are located in the region of the municipalities of Santo Antônio de Leverger and Barão de Melgaço, on the left bank of the Cuiabá River (Figure 1). The Chacororé Lake, during the rainy season, is connected to an extensive floodable area to the northeast and, to the north, is connected to the Cuiabá River and Sinhá Mariana.

The genesis of the Sinhá Mariana Lake lies in the widening of the canal of the Mutum River, which directly influences is morphometry. It is deeper and more elongated than the Chacororé and remains connected to the Cuiabá River throughout the year.

The fish were captured during the year 2003, in the periods corresponding to high water (rainy season - March), receding (May), and low water (dry season - September), at six sampling sites. In Chacororé Lake, sampling was carried out in stands of Eichhornia crassipes (P1) (21k 0615537 and 8196165 UTM), in Sinhá Mariana Lake, samples were collected at two points: the area where the E. crassipes stands (P2) (16 $20^{\prime} 31^{\prime \prime} \mathrm{S}$ and $\left.55^{\circ} 54^{\prime} 56,8^{\prime \prime} \mathrm{W}\right)$ and the E. azurea stands (P3) (16 $16^{\circ} 58^{\prime \prime} \mathrm{S}$ and $\left.55^{\circ} 55^{\prime} 03^{\prime \prime} \mathrm{W}\right)$ are influenced by Chacororé Lake, and the region influenced by the waters of the Mutum River - stands of E. crassipes (P4)

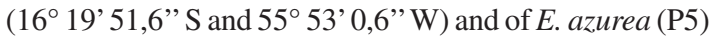
(16 $26^{\circ} 07^{\prime}$ ' $S$ and $55^{\circ} 52^{\prime} 17^{\prime}$ 'W). The Mutum River, the
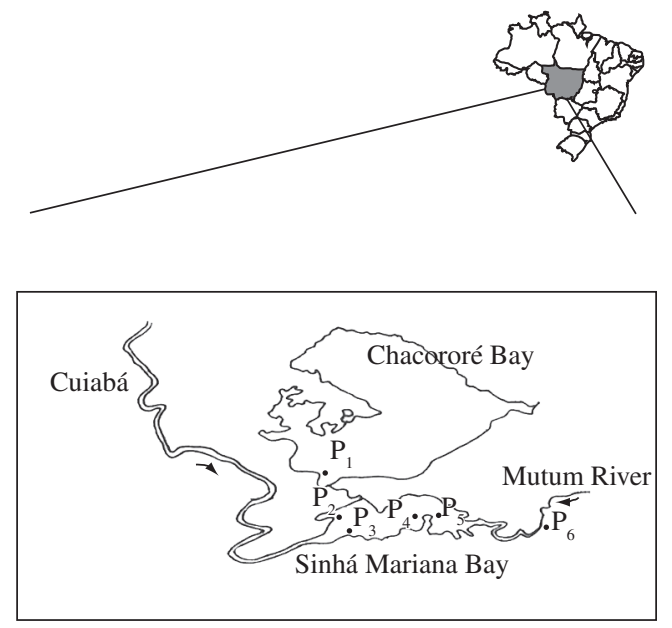

Figure 1. Location of the sampling sites in the study area; the arrows indicate the direction of the water flow.

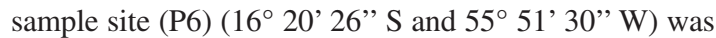
covered by stands of E. azurea. In Chacororé Lake and the Mutum River, there is a significant predominance of Eichhornia crassipes and E. azurea, respectively, which is the justification for having only one sampling point in each of these localities.

The collection was conducted using a drag net ( $25 \mathrm{~m}$ long, $5 \mathrm{~m} \mathrm{high,} \mathrm{and} 5 \mathrm{~mm}$ mesh) between the hours of 11 and 12 hours. The fish were fixed in $10 \%$ formaldehyde and later preserved in $70 \%$ alcohol. Species identification was carried out with the aid of the key system proposed by Britski et al. (1999). The samples were deposited in the Support Laboratory of the Biosciences Institute of the Federal University of Mato Grosso (UFMT).

The following physical-chemical variables of the water were recorded in the field, around the edges of the macrophyte stands: temperature $\left({ }^{\circ} \mathrm{C}\right), \mathrm{pH}$, depth $(\mathrm{m})$, transparency $(\mathrm{m})$, turbidity (NTU), and conductivity $\left(\mu \mathrm{Scm}^{-1}\right)$.

The associations of fish were analyzed by means of the Jackknife richness estimate (Krebs, 1998), relative abundance (\%), number of individuals $(\mathrm{N})$, richness $(\mathrm{S})$, Berger-Parker dominance index (d), and Simpson diversity index (D) (Magurran, 1988).

To analyze $\beta$ diversity, which was verified among the different hydrological periods for each sampling site, as well as among the six sampling sites for each hydrological period, the Sørensen $\left(\mathrm{C}_{\mathrm{n}}\right)$ similarity index, modified by Bray and Curtis (1957), was used.

To test the hypothesis that the distribution of the species in the sampling sites varies in relation to the limnological variables, an ordering technique was applied - Canonical Correspondence Analysis (CCA) - to the matrices of biotic (fish) and limnological variables, with the assistance of the PC-ORD program.

\section{Results}

In general, the six sampling sites showed variation in the values of the limnological variables with respect to the hydrological period. The greatest variation in water level was observed at P6, which measured $3.3 \mathrm{~m}$ during the high water season and only $0.59 \mathrm{~m}$ during the low water season. Sampling site P1 presented the least variation in depth, with $2.95 \mathrm{~m}$ when waters were receding, and $2.2 \mathrm{~m}$ during the period of low water, varying only $0.75 \mathrm{~m}$ (Figure 2a).

The highest mean values of water temperature (about $31{ }^{\circ} \mathrm{C}$ ) and turbidity (36.8 NTU) occurred in the low water period, when the lowest depth was $0.87 \mathrm{~m}$. In Figure $2 b$, it can be observed that the Mutum River (P6) presented the lowest water temperatures in the three seasons studied, varying from $26^{\circ} \mathrm{C}$ in the period of receding waters, to $27.1{ }^{\circ} \mathrm{C}$ in the low water period, whereas the highest water temperatures were recorded in Chacororé Lake (P1), $28.7^{\circ} \mathrm{C}$ in the period of high water and $33.7^{\circ} \mathrm{C}$ in the period of low water. 
The highest mean values of $\mathrm{pH}$ (7.0-7.37) were observed at sampling site $\mathrm{P} 1$, in the three hydrological periods. The lowest value was 4.68 , observed at site P6 during the low water period (Figure 2c).

Considering all the sampling sites, water transparency values varied from 0.3 (at P1, low water) to $1.80 \mathrm{~m}$ (at P6, receding water). As shown in Figure 2d, the sites sampled in the region of Sinhá Mariana where water flows in from the Mutum River (P4 and P5) have higher transparency values than those that receive waters from the Chacororé (P2 and P3).

The higher and the lower turbidity values were observed during the periods of low and the high water, respectively. The lowest mean values (below 30 NTU) were found at P4, P5 and P6 sites, controlled by Mutum River and the highest mean values (above 30 NTU) in sites P1, P2, and P3 influenced by Chacororé water (Figure 2e).

The electrical conductivity values varied between $58 \mu \mathrm{Scm}^{-1}$ at $\mathrm{P} 1$ in the period of high water, and $5.86 \mu \mathrm{Scm}^{-1}$ at sampling site P5, during low water. For
Sinhá Mariana Lake, the areas influenced by the waters of the Chacororá presented higher electrical conductivity compared to those that received water from the Mutum River (P6), as shown in Figure 2f.

A total of 3,510 fish were captured, distributed among 6 orders, 22 families, and 82 species. Of these, 44 (53.0\%) were Characiforms, 16 (19.3\%) Siluriformes and $11(13.2 \%)$ Perciformes, and individuals pertaining to the orders Gymnotiformes, Cyprinodontiformes and Synbranchiformes together represented $14.5 \%$ of the species captured.

The richness, estimated using the Jackknife index calculated for the environment studies, was 104.7 (dp 5.93), with a 5\% confidence interval (79.2 to 130.2), with 34 species occurring only in the locale sampled. Thus, the collection carried out in the macrophyte stands corresponds to $78.3 \%$ estimated richness for the lakes and river in the system, since 82 species were sampled.

Regarding abundance, Characiformes were dominant, representing $42.4 \%$ of the total number of individu-

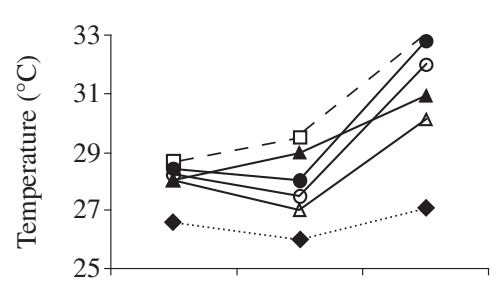

(a)

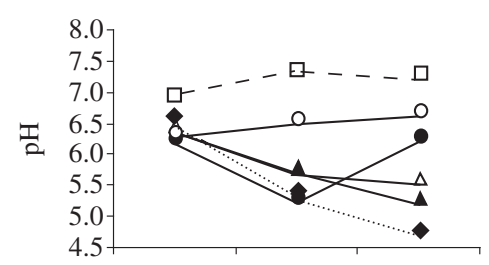

(b)

(c)
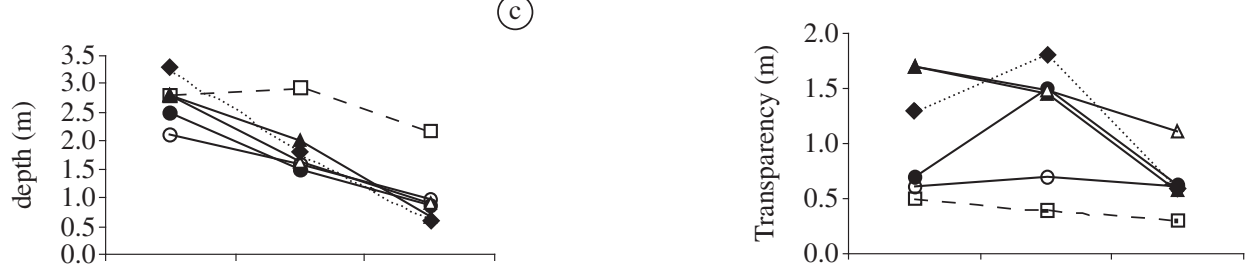

(d)

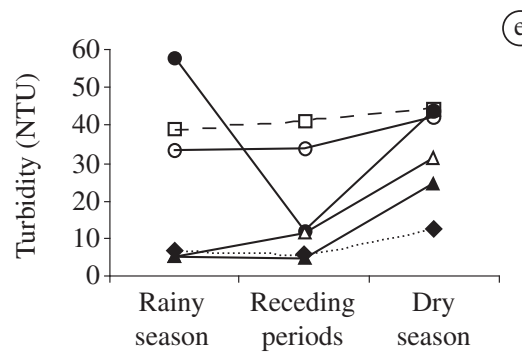

(e)

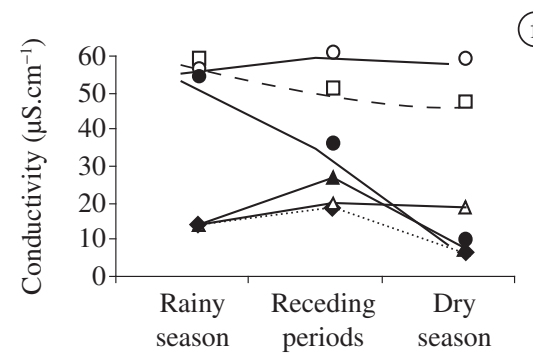

(f)

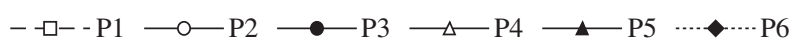

Figure 2. Values of the limnological variables measured at the sampling sites in the periods of high, receding, and low water. A, temperature; B, pH; C, depth; D, transparency; E, turbidity; F, conductivity. P1, Chacororé; P2, Chacororé-Sinhá Mariana in a stand of Eichhornia crassipes; P3, Chacororé-Sinhá Mariana in a stand of Eichhornia azurea; P4, Sinhá-MarianaMutum river in a stand of E. crassipes; P5, Sinhá-Mariana-Mutum River in a stand of E. azurea; and P6, Mutum River. 
als sampled, followed by Gymnotiformes (30.1\%) and Perciformes (14.3\%).

The families Characidae, Sternopygidae, Cichlidae and Hypopomidae corresponded to $71.2 \%$ of the fish captured in the six sampling sites. In general, Characidae, Cichlidae and Sternopygidae, as well as Cichlidae, predominated in the period of high water as well as receding water. In the low water, however, Cichlidae was not dominant in any of the sampling sites, with Loricariidae, Sternopygidae and Characidae being more abundant.

At the Chacororé Lake sampling site (P1), a total of 1,279 fish were captured, 39 in the period of high water, 812 in the receding water, 428 in the low water period, belonging to 45 species. In the periods of high and receding water, the Sternopygidae family was most abundant, with 17 and 335 individuals sampled, respectively. In the dry season, however, the Characidae family was dominant, with 96 individuals sampled. The most abundant species in each hydrological period are presented in Figure 3.

The Berger-Parker index shows that Eigenmannia trilineata was the dominant species at $\mathrm{P} 1$ during the three hydrological periods, with values around $d=0.42$ during the period of high and receding waters, and $d=0.18$ in the low water period, with the same value found for Pyrrhulina australis in the latter period, as well; the diversity value varied between $\mathrm{D}=0.10$ in the low water and $\mathrm{D}=0.23$ in the period of receding water.

At site P2, 366 individuals were captured - the lowest local abundance -26 of which were captured in the high water season, 215 in the receding water, and 95 in the period of low water, distributed among 32 species. The Characidae family was the most abundant in the periods of high and low water, with 16 and 35 individuals, respectively. During the period of receding water, however, Curimatidae was dominant, with 74 individuals sampled.

With respect to species, Prionobrama paraguayensis was dominant in high water $(\mathrm{d}=0.27)$ and low water ( $d=0.16)$, followed, in both seasons, by Moenkhausia sp. In the period of receding water, Curimatopsis myersi was the most abundant species $(\mathrm{d}=0.34)$, followed by Hyphessobrycon eques and Hypoptopoma inexpectatum (Figure 4). The period with the highest diversity was that of low water, with $\mathrm{D}=0.09$, and the lowest was recorded in the period of receding water, with 0.17 , which is, nevertheless, a high value.

Of the total of 468 examples of fish captured at P3, 72 were captured during high water, 290 in receding water, and 106 in low water, distributed among 53 species, making this the sampling site with the highest richness. Characidae was the most abundant family in high water (64 individuals), Sternopygidae (119) in receding water, and Loricariidae (41) in low water.

In relation to the specific dominance for each hydrological period, the Berker-Parker index shows the dominant species to be Moenkhausia sp. in high water $(\mathrm{d}=0.50)$, Eigenmannia trilineata $(\mathrm{d}=0.27)$ in reced- ing water, and Rineloricaria sp. $(\mathrm{d}=0.21)$ in low water (Figure 5). The highest diversity at this site occurred during low water $(\mathrm{D}=0.10)$ and receding water $(\mathrm{D}=0.11)$, which is reflected in the low dominance values compared to the high water period.

At sampling site P4, 511 individuals were collected, distributed among 36 species; 50 individuals were collected in high water - of which 24 belong to Cichlidae - 174 in receding water, and 287 in the low water. In these two periods, the Characidae family had higher representation in abundance, with 95 and 70 individuals, respectively.

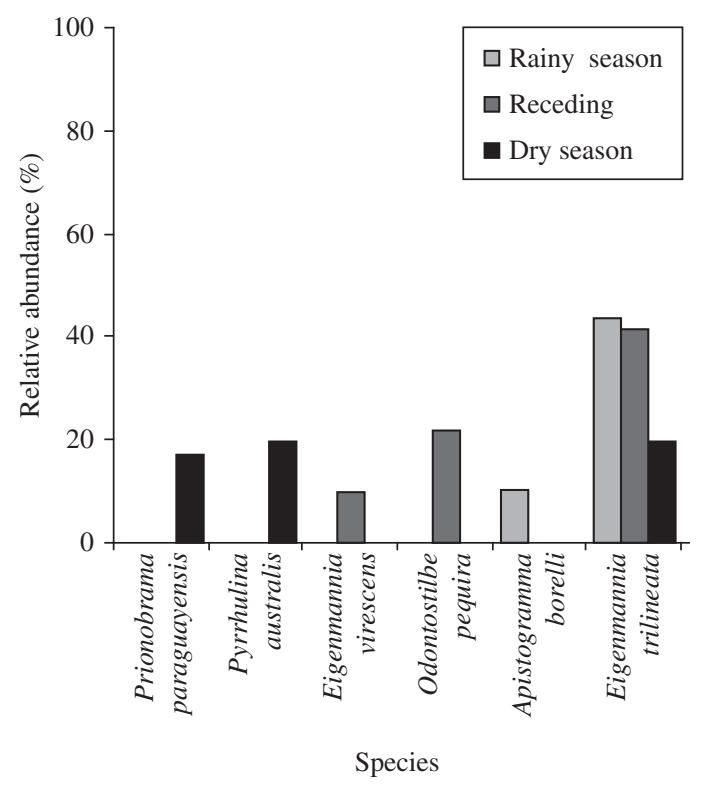

Figure 3. Species abundance in the periods of high, receding, and low water, at sampling site P1.

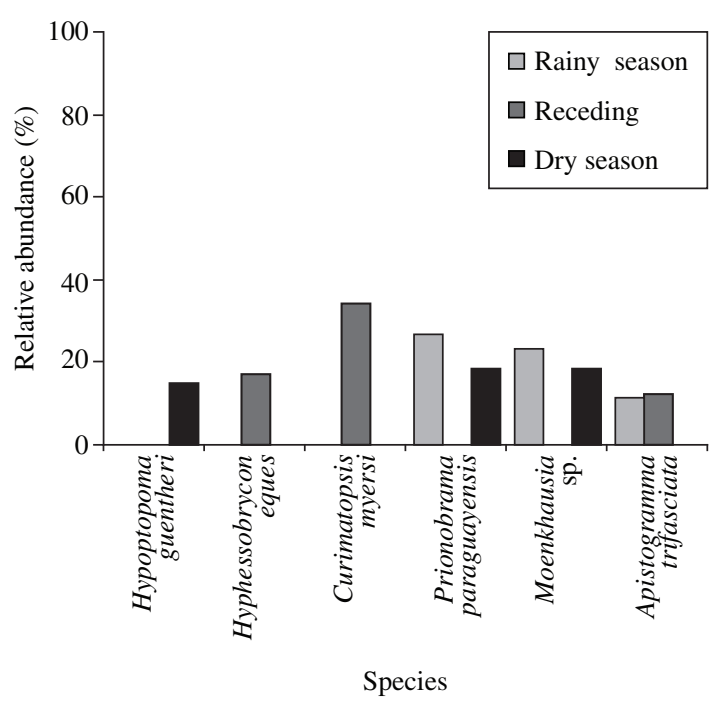

Figure 4. Species abundance in the periods of high, receding, and low water, at sampling site P2. 
In the high water period, Apistogramma borelli was the dominant species with $\mathrm{d}=0.30$, while Moenkhausia $\mathrm{sp}$. was dominant in the period of receding water $(\mathrm{d}=0.38)$, and Pyrrhulina australis in the low water period $(\mathrm{d}=0.16)$, as shown in Figure 6. The low dominance observed in the dry season is reflected in the higher local diversity $(\mathrm{D}=0.08)$.

Of the 380 individuals of fish captured at sampling site $\mathrm{P} 5$, belonging to 31 species, seven occurred in high water, 148 in receding water, and 225 in the low water period. In each hydrological period, a different group was dominant: in high water, the Hypopomidae family had the largest number of individuals (2), with Hypopomus sp. A presenting a dominance of $d=0.28$; during the period of re-

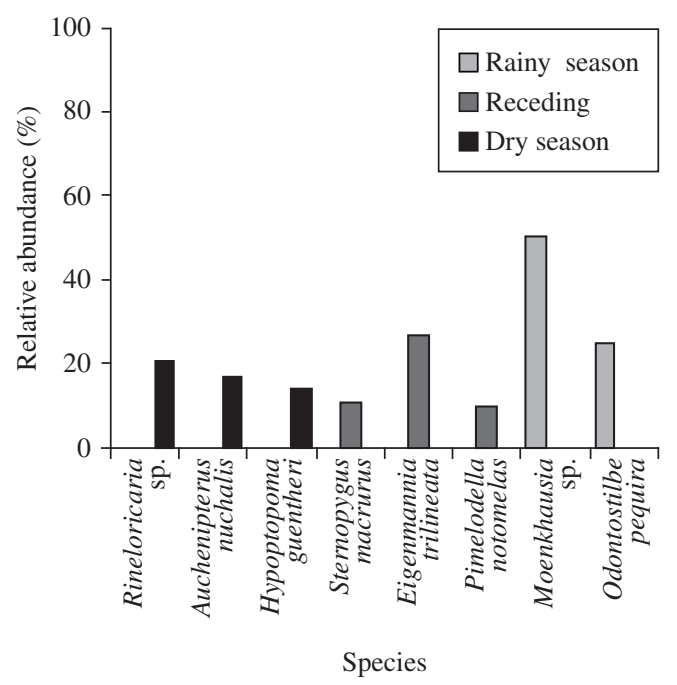

Figure 5. Species abundance in the periods of high, receding, and low water, at sampling site P3.

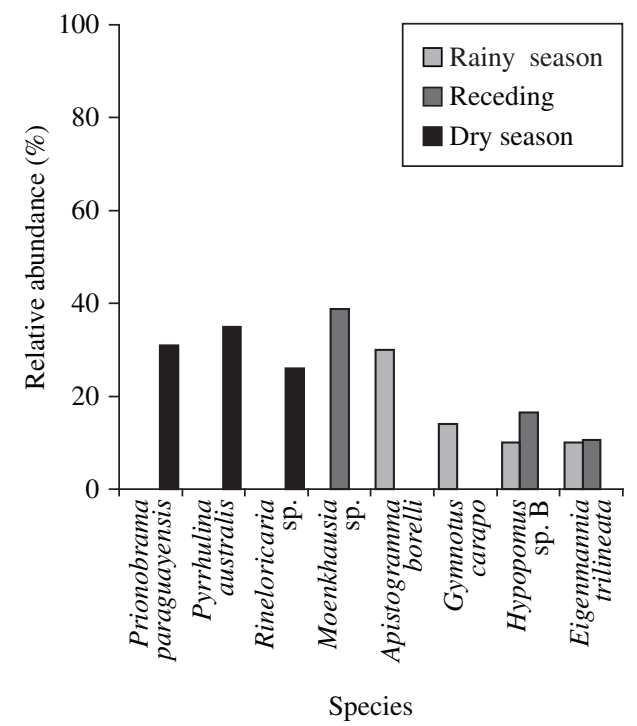

Figure 6. Species abundance in the periods of high, receding, and low water, at sampling site P4. ceding water, a predominance of Characidae (92 fish sampled) was observed, with Hemigrammus ureyi presenting $\mathrm{d}=0.19$; in low water, Loricariidae were more abundant, with 184 individuals, all of the species Hypoptopoma inexspectatum $(\mathrm{d}=0.82)$. The highest diversity value found at this locale was $\mathrm{D}=0.04$, in high water, due to the homogeneity of the sample. The most abundant species at sampling site P5 are presented in Figure 7.

In the Mutum River (P6), 536 individuals were collected, distributed among 45 species - 170 in high water, 95 in receding water, and 271 in the low water period. The Cichlidae family presented the largest number of individuals in high as well as receding water, with 94 and 48 individuals, respectively. In low water, Characidae was observed to be dominant, with 197 individuals.

Upon analyzing the specific dominance, Laetacara dorsigera obtained $\mathrm{d}=0.18$ in high water and 0.41 in receding water, and Poptella paraguayensis obtained 0.28 in low water. The other dominant species in the periods studied are presented in Figure 8. The Simpson diversity yields very similar values for the three hydrological periods, varying from $\mathrm{D}=0.10$ to $\mathrm{D}=0.14$.

When the data are analyzed with respect to $\beta$ diversity, the similarity values between the hydrological periods for the same sampling site were relatively low, with the highest similarity $\left(\mathrm{C}_{\mathrm{n}}=0.27\right)$ being observed among the ichthyofauna communities at P1 (Chacororé Lake) between the periods of receding and low water; for the same periods, similarity of $\mathrm{C}_{\mathrm{n}}=0.26$ was observed at P3 (ChacororéSinhá Mariana in E. crassipes stands). This shows that the most similar fish communities coincide by only $27 \%$.

Just as little similarity was observed among the fish communities at the same sampling site when comparing the different hydrological periods, the same was also true when analyzing similarity among the fish communities at different sampling sites during the same hydrological period. In the periods of high and low water, the highest similarity was found between P4 and P6 $\left(C_{n}=0.39\right.$ and $C_{n}=0.34$, respectively), and during the period of receding water, the highest similarity was observed between P5 and P6 $\left(C_{n}=0.39\right)$.

Canonical Correspondence Analysis (CCA) for the high water period indicates that the occurrence of Apistogramma trifasciata and Crenicichla edithae at sampling site P6 is associated with water transparency $(1.3 \mathrm{~m})$. In the period of receding water, the abundance of Hypopomus sp. B (Britski et al., 1999), Gymnotus carapo, Leporinus striatus, Eigenmannia trilineata and E. virescens at $\mathrm{P} 1$ and $\mathrm{P} 4$ is associated with the turbidity of the water, the values found at each site being 41.0 (the highest recorded for this period) and 11.5 NTU, respectively. In the low water period, there was a positive correlation between the presence of Synbranchus marmoratus, Eigenmannia trilineata and electrical conductivity at sampling site P1 $\left(49 \mu \mathrm{Scm}^{-1}\right)$, and also for Characidium aff. zebra, Apistogramma borelli and Pimelodella notomelas at P2 $\left(60 \mu \mathrm{Scm}^{-1}\right)$; these were the highest values observed for electrical conductivity in this period. 


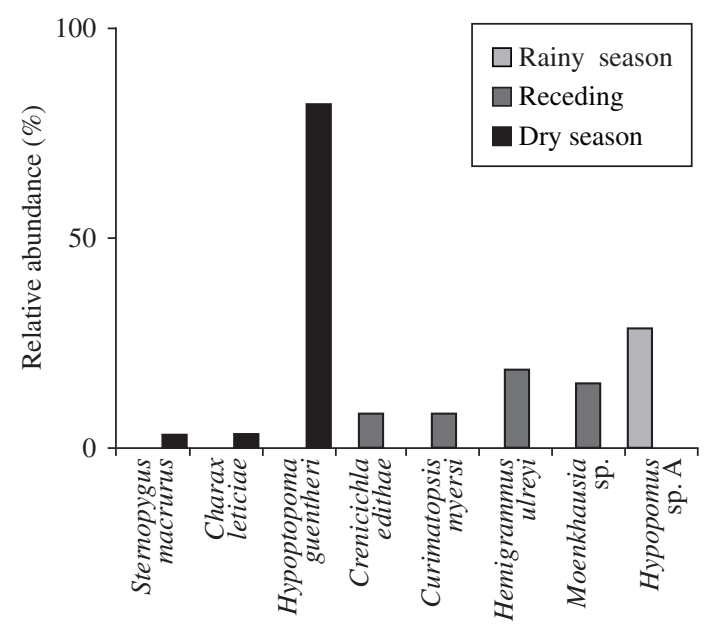

Species

Figure 7. Species abundance in the periods of high, receding, and low water, at sampling site P5.

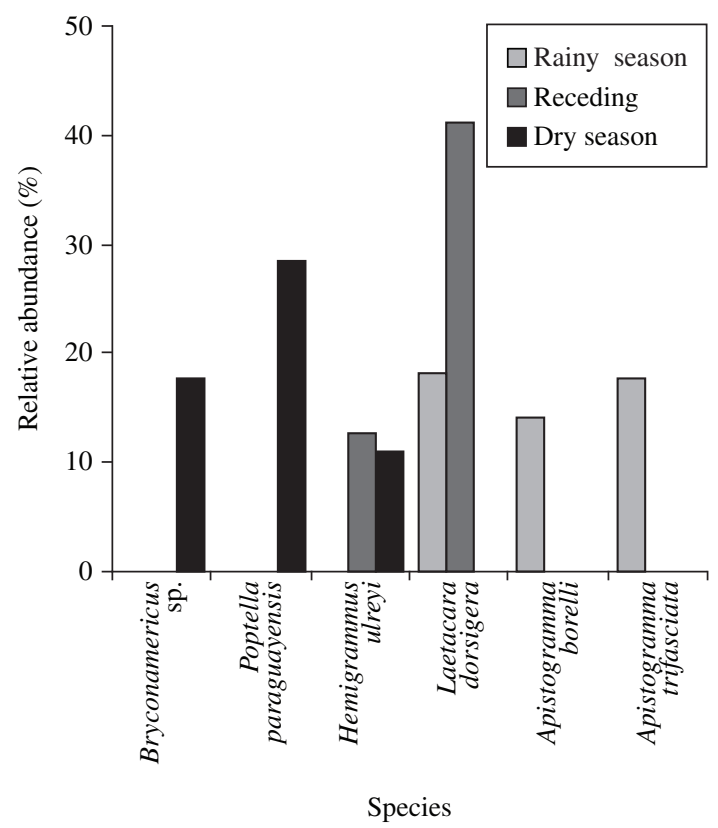

Figure 8. Species abundance in the periods of high, receding, and low water, at sampling site P6.

\section{Discussion}

In general, with respect to the physical-chemical variables of the water, the findings of the present study corroborate those of Pinto-Silva (1980), Pinto-Silva (1991), da Silva and Esteves (1995), da Silva and Figueiredo (1999), Nunes (2003), showing a trend toward increasing homogenization of the values of these variables in the period of high water, with a clear differentiation during the low water period, due to the flood pulse.
The limnological analysis showed, for the four sampling sites in Sinhá Mariana Lake, that the physical-chemical characteristics of the water were distinct regardless of the species of macrophyte present in the locale sampled. This may be one of the factors responsible for the dominance of different fish species at sampling sites P2 and P5 during each of the hydrological periods sampled.

The differentiation in the limnological variables may also be reflected in the composition of the ichthyofauna communities at sites $\mathrm{P} 1$ and $\mathrm{P} 2$. The CCA analysis confirms the influence of the electrical conductivity of the water on the occurrence of some fish species in these locales. At P1, the dominance of Eigenmannia trilineata during the three hydrological periods appears to be related to the high electrical conductivity values observed at that site.

The dominance of individuals from the order of Characiformes observed in this study, as well as its high richness, were also reported by Súarez (1998), Britski et al. (1999), and Resende et al. (2000) for the Pantanal region, and by Catarino and Val (2000), in the Amazon basin, Casatti et al. (2003), Lima (2003) and Oliveira and Garavello (2003). Thus, as observed by Pelicice et al. (2005) in regions with a high density of vegetation, another important component of the community in this Lake system, in addition to caraciformes, is the Gymnotiformes (about $30 \%$ of the local abundance).

Regarding the number of species found, Delariva et al. (1994) (apud Agostinho et al., 2003) recorded 30 species associated with macrophyte stands in different environments of the Rio Paraná floodplains, 21 of which were Characiformes and only six Siluriformes. Similarly, the highest richness found in the present study was also of the Characiformes, followed by Siluriformes. Despite the differentiation in species sampled in this hydrographic basin, this demonstrates a structural similarity of the fish community when observed in relation to large taxonomic groups.

On the other hand, the large number of individuals sampled (3510) can be justified: 1) by the fact that detritus of aquatic macrophytes are important food sources for young fish of migratory caraciformes, and 2) even if not consumed directly, they play a relevant role in the trophic structure of the fish communities (Saint-Paul and Lakeley, 1979; Goulding, 1980; Mittelbach, 1981 apud Agostinho et al., 2003; Agostinho et al., 2003), since algae and macroinvertebrates adher to their roots and stems. Also, according to Cunico et al. (2002), the connection of the main canal (in this study, the Cuiabá River) with lateral areas makes it possible for the young of many species to enter the lakes and exploit the large amount of food and shelter.

The greater abundance of Siluriformes observed in the low water period is probably due to the physicalchemical conditions of the water, which were unfavorable to individuals from other orders; the lower transparency of the water in the low water period, resulting from the high turbidity, favors the occurrence of Siluriformes which, according to Lewis et al., (2000) are tactile and 
chemo-receptors, and of Gymnotiformes, which are electro-sensitive, to the detriment of Characiformes, which are visually-oriented organisms.

In addition, the high abundance of Gymnotiformes and small cyclids, according to Henderson and Hamilton (1995), is explained by the fact that these species are reluctant to migrate from areas of floating vegetation into open water, because of the pressure of predation.

The low similarity of the ichthyofauna in the sampling sites, as demonstrated by the values obtained in the $\beta$ diversity analysis, by the dominance of different species in each sample, and by the local richness, indicates that each of the sampling sites has a resident fish community that changes in accordance with changes in the water level.

In addition, the results of the multivariate analysis show that the different communities in each sampling site are formed in accordance with the environmental conditions at the sampling sites, as the different limnological variables, such as conductivity, transparency, and turbidity of the water, associated positively with the presence of diverse species of fish in the locales and the hydrological periods studied.

Súarez et al. (2004), analyzing characteristics of lakes and the abundance of predators in the Pantanal of Nhecolândia, Mato Grosso do Sul, found that the time of isolation from and the distance to the main canal, and the depth of the lakes, appeared to explain the differences found in the ichthyofauna sampled.

Aquatic macrophytes thus appear to be, for the Chacororé-Sinhá Mariana Lake system and the Mutum River, a safe environment for the establishment of different communities of resident (and migratory, based on occasional observation) fish, in accordance with the characteristics of the water, which change with the flood pulse.

Thus, measures to minimize environmental impacts in this region should be encouraged and carried out in such a way as to conserve the alterations in the volume of water as well as the fish communities in this dynamic environment.

Acknowledgements - The authors would like to thank: FAPEMAT (Fundação de Amparo à Pesquisa de Mato Grosso), for funding the project entitled "Bases para o Monitoramento da Biodiversidade no Sistema de Baías Chacororé - Sinhá Mariana, no Pantanal Mato Grossense", Process nº. 322127/052001.E; CAPES for the academic fellowship granted to the first author and the Masters Program in Ecology and Biodiversity Conservation, Biosciences Institute, Federal University of Mato Grosso, for the opportunity to acquire the Masters degree; and to Dra. Maria Gercília Mota Soares and Profa. Iolanda Silva for the support at all stages of the research.

\section{References}

AGOSTINHO, AA., GOMES, LC. and JULIO Jr, HF., 2003. Relações entre macrófitas aquáticas e fauna de peixes. In Thomaz, SM. and Bini, LM. Ecologia e manejo de macrófitas aquáticas. Maringá: Editora da Universidade Estadual de Maringá.
BRAY, JR. and CURTIS, CT., 1957. An ordination of the upland forest communities of southern Wisconsin. Ecol. Monogr, vol. 27 , p. 325-349.

BRITSKI, HA., SILIMON, KZS. and LOPES, BS., 1999. Manual de identificação de peixes do Pantanal. Brasília - DF: Empresa Brasileira de Pesquisa Agropecuária.

CATARINO, MF. and VAL, AL. Abundance and distribution of fish in litter banks of the Amazon. [2004, Agosto 15]. Available from: www.heb.pac.dfv-mpo.gc.ca/congress/2000.

CATELLA, AC. and PETRERE Jr., M., 1998. Body-shape and food habits of fish from Baía da Onça, a Pantanal flood plain lake, Brazil. Verh. Internat. Verein. Limnol, vol. 26, p. 2203-2208.

-, 1996. Feeding patterns in a fish community of Baía da Onça, a floodplain lake of the Aquidauana river, Pantanal, Brazil. Fish. Manag. Ecol, vol. 3, p. 229-237.

CASATTI, L., MENDES, HF. and FERREIRA, KM., 2003. Aquatic macrophytes as feeding site for small fishes in the Rosana reservoir, Paranapanema river, southeastern Brazil. Braz. J. Biol, vol. 63, no. 2, p. 213-222.

CUNICO, AM., Da GRAÇA, WJ., VERÍSSIMO, S. and BINI, LM., 2002. Influência do nível hidrológico sobre a assembléia de peixes em lagoa sazonalmente isolada da planície de inundação do alto rio Paraná. Acta Sientiarum, vol. 24, no. 2, p. 383-389.

Da SILVA, CJ. and ESTEVES, FA., 1993. Biomass of three macrophytes in the Pantanal of the Mato Grosso, Brazil. Int. J. Ecol. Environ. Sci., vol. 19, no. 1, p. 11-23.

-, 1995. Dinâmica das características limnológicas as baías Porto de Fora e Acurizal (Pantanal de Mato Grosso) em função da variação do nível da água. In Esteves, F.A. (Ed). Estrutura, funcionamento e manejo de ecossitemas brasileiros. Rio de Janeiro: PPGEUFRJ. Serie Oecologia Brasiliensis, 597p.

HENDERSON, PA. and HAMILTON, HF., 1995. Standing crop and distribution of fish in drifting and attached floating meadow within an Upper Amazonian varzea lake. Journal of Fish Biology, vol. 47, p. 266-276.

JULIO Jr., HF. (Org). Ictiofauna PELD alto rio Paraná. [2004, Setembro 21]. Available from: www.peld.uem.br/Relat2001/ pdf/componente_bióticos_lictiofauna.PDF

KREBS, CH., 1998. Programs for ecological methodology. 2 ed. [S.L.]: Published by Addison-Welsey.

LEWIS Jr, WM., HAMILTON, SK., LASI, MA., ROGRIGUÉZ, M. and SAUNDERS III, JF., 2000. Ecological Determinism on the Orinoco floodplain. BioScience, vol. 50, no. 8, p. 681-692.

MACHADO, FA., 2003. História Natural de Peixes do Pantanal: com destaque em hábitos alimentares e defesa contra predadores. [Tese]. Campinas: UNICAMP, Universidade Estadual de Campinas, 2003.

MAGURRAN, AE., 1988. Diversidad ecológica y su medición. Barcelona: Ediciones Vedrà.

MOURA, NA. 2000. Influência de fatores físico-químicos e recursos alimentares na migração lateral de peixes no lago Chacororé, Pantanal de Barão de Melgaço, Estado de Mato Grosso. [Dissertação]. INPA, Insituto Nacional de Pesquisas da Amazônia.

NUNES, JRS., 2003. Dinâmica temporal e espacial de nutrientes na biomassa de Eicchornia crassipes (Mart.) Solms no sistema de baías Chacororé-Sinhá Mariana, Pantanal Mato-grossense, 
Barão de Melgaço, MT. Cuiabá. [Dissertação de Mestrado]. Mato Grosso: Universidade Federal de Mato Grosso, p. 144.

OLIVEIRA, AK. and GARAVELLO, JC., 2003. Fish assemblage composition in a tributary of the Mogi Guaçu river basin, Southeastern Brazil. Iheringia, Sér.Zool, vol. 93, no. 2 p. 127-138.

OLIVEIRA, RD. and NOGUEIRA, FMB., 2000. Characterization of the fishes and of subsistence fishing in the Pantanal of Mato Grosso, Brazil. Rev. Bras. Biol. vol. 60, no. 3, p. $435-445$

PELICICE, FM., AGOSTINHO, AA., THOMAZ, SM., 2005. Fish assemblages associated with Egeria in a tropical reservoir: investigating the effects of plant biomass and diel period. Acta Oecologica, vol. 27, p. 9-16.

PENHA, JMF, Da SILVA, CJ. and BIANCHINI Jr, I., 1998. Análise do crescimento da macrófita aquática Pontederia lanceolata em áreas alagáveis do Pantanal matogrossense, Brasil. Rev. Bras. Biol., vol. 58, no. 2, p. 287-300.

PINTO, AA., Da SILVA, CJ., GIRARD, P., SOUZA, MD. and NOGUEIRA, F., 1999. El pulso de inundación y la limnología de la laguna Sinhá Mariana en el Pantanal de Mato Grosso, Brasil. Rev. Bol. De Ecol., vol. 6, p. 19-26.

PINTO-SILVA, V., 1980. Variações diurnas de fatores ecológicos em quatro lagos naturais do "Pantanal Mato-grossense" e seu estudo comparativo com dois lagos da Amazônia Central e um lago artificial da Represa do Lobo. ("Broa" São Carlos, SP). [Dissertação de Mestrado]. São Carlos: Universidade Federal de São Carlos, p. 281.

PINTO-SILVA, V. 1991. Variação diurna dos principais parâmetros limnológicos nos lagos Recreio e Buritizal, Pantanal Matogrossense, barão de Melgaço - MT. [Tese] São Carlos: Universidade Federal de São Carlos - UFSCar.

POTT, VJ. and POTT, A., 1997. Checklist das macrófitas aquáticas do Pantanal, Brasil. Acta Botânica Brasílicas, vol. 11, no. 2, p. 215-227.

RESENDE, EK., 2000. Trophic structure of fish assemblages in the lower Miranda river, Pantanal, Mato Grosso do Sul state, Brazil. Rev. Bras. Biol. vol. 60, no. 3, p. 389-403.

SÚAREZ, YR. 1998. Ecologia de comunidades de peixes em lagoas do Pantanal da Nhecolândia, Corumbá, Mato Grosso do Sul. [Dissertação]. Mato Grosso do Sul: Universidade Federal de Mato Grosso do Sul.

SÚAREZ, YR., PETRERE Jr, M. and CATELLA, AC., 2004. Factors regulating diversity and abundance of fish communities in Pantanal lagoons, Brazil. Fish. Manag and Ecol, vol. 11, p. $45-50$.

WANTZEN, KM., MACHADO, FA., VOSS, M., BORISS, H., and JUNK, WJ., 2002. Seasonal isotopic shifts in fish of the Pantanal wetland, Brazil. Aquat. Sci., vol. 64, p. 239-251. 